\title{
O venturoso sumo de limão: orientações voltadas ao tratamento do cólera no semanário $O$ Araripe em meados do oitocentos
}

The fortunate lemon juice: guidelines to the cholera treatment published on the weekly $O$ Araripe newspaper in the middle of the 18th century

Jucieldo Ferreira Alexandre*

Palavras-chave:

Cólera

Imprensa

Tratamentos médicos

Keywords:

Cholera

The press

Medical treatments
Resumo: Este artigo analisa as orientações e receitas publicadas no jornal O Araripe - órgão impresso no interior do Ceará em meados do século XIX - a respeito do cólera-morbo. A infinidade de textos veiculados pelo jornal aponta para as divisões da medicina do período e para os usos de remédios feitos à base de ervas, frutas e outros produtos populares, demonstrando a circularidade de saberes que permeou a conjuntura epidêmica.

Abstract: This article analyzes guidelines and recipes published on the $\mathrm{O}$ Araripe newspaper - printed periodical inside Ceará in the middle of the 19th century - about cholera morbus. The infinity of texts propagating by newspaper point to the medicine's divisions of the period and to the uses of remedies made of herbs, fruits and other popular products, demonstrating the circularity of knowledge that permeated the epidemic conjuncture.

Recebido em 7 de outubro de 2017. Aprovado em 21 de dezembro de 2017.

\section{Introdução}

Em maio de 1855, o cólera-morbo atingiu o Brasil. O foco inicial de contaminação foi o Pará, mas logo a doença espraiou-se para outros pontos do Império, matando cerca de duzentos mil pessoas entre 1855 e 1856, das quais cerca de cento e trinta mil habitavam as províncias do Norte (DINIZ, 2011). No mesmo ano da chegada do cólera, saiu a público o semanário $O$ Araripe. Impresso em Crato, sul do Ceará, o jornal estava intrinsecamente ligado ao contexto histórico vivenciado à época pelo lugar e aos interesses de segmentos das elites locais: profissionais liberais, proprietários de terra e comerciantes ligados ao Partido Liberal em busca de legitimação político-social.

Entre 1855 e 1865, excetuando os textos dedicados às contendas políticas - nos quais conservadores e liberais se atacavam -, nenhum tema obteve tanto espaço n'O Araripe como o cólera.
Nele divulgou-se a marcha da "peste", as localidades atacadas, o número de vítimas, os problemas de abastecimento, indicou-se remédios em voga e orações tidas como profiláticas, entre outros textos relacionados ao assunto.

O espaço ocupado pelo cólera no semanário aponta para a historicidade das doenças. Para Claudine Herzlich, por ser evento ameaçador e modificar a vida das pessoas e o equilíbrio social coletivo, a doença sempre propicia "uma necessidade de discurso, a necessidade de uma interpretação complexa e contínua da sociedade inteira" (HERZLICH, 2005). Ante a força mortal da doença, especialmente de uma epidemia, diferentes grupos sociais podem tecer diversas formas de explicar e combater o fenômeno, produzindo leituras particulares sobre a sociedade na qual estão inseridos.

Em época tão complexa e tensa - como a da aproximação do cólera em relação ao Crato -,

\footnotetext{
* Professor Assistente I do Curso de História da Universidade Federal do Cariri, Campus Icó-CE. Doutorando em História Social pela Universidade Federal Fluminense. Mestre em História e Cultura Histórica pela Universidade Federal da Paraíba. Graduado em História pela Universidade Regional do Cariri. E-mail: <jucieldo.alexandre@ufca.edu.br>.
} 
as representações impressas n'O Araripe sobre o fenômeno foram múltiplas, resultando em oscilação ou junção entre vários saberes. Ao tratar da enfermidade, o órgão de imprensa combinou de forma criativa discursos políticos, religiosos, científicos e populares, demonstrando, assim, o caleidoscópio de olhares com que a doença foi apreendida então, ou seja, como o cólera foi representado pelos sujeitos históricos, responsáveis pelo jornal, a partir do lugar social ocupado por eles.

Neste artigo, demonstro o quanto a manifestação da epidemia acabou expondo as divisões e debilidades da medicina acadêmica e a incapacidade concreta dos profissionais da saúde em inibir o cólera em meados do oitocentos. Neste sentido, as orientações e receituários impressos n'O Araripe apontam para como os "facultativos" - terminologia pela qual os médicos eram também conhecidos em meados do XIX - fizeram experiências assimiladoras de produtos curativos populares, indiciando uma circularidade de saberes terapêuticos.

\section{O venturoso sumo de limão}

O cholera que tanto tem afligido a raça humana, esse maldito judéo errante, vai-se aproximando de nossa comarca, pelo lado do Pajaù de Flores[...]; esta noticia porém não deve aterrar nossa população, porque a Providencia nos a mostrado o remedio eficas contra esse mal; pelo que devemos tomar todas cautelas para no caso de aparicer entre nós a epedemia, estarmos preparados para a receber com o vertuoso 'SUMO DO LIMÃO' esse agente medecinal, que tantos fructos tem produsido no Pará, também obrará milagrosamente entre nós. DEOS protege a quem crer em sua infinita MIZERICORDIA, e secundados nella não devemos aterrar com a presença do mal, porque como já dissemos a MIZERICORDIA DE DEOS, E O SUMO DO LIMÃO, providencialmente descuberto, nos fará encarar com o sangue frio essa epedemia e della zombarmos. (O ARARIPE, 1856a, p. 4). ${ }^{1}$
O documento acima foi divulgado pelo O Araripe, em 5 de janeiro de 1856. A publicação sobre as vantagens do limão no tratamento do cólera veio a lume no período de manifestação do flagelo do cólera em Pernambuco, província fronteiriça ao Cariri cearense, região de circulação principal do semanário. Anunciando a proximidade do "mal", a nota afiança: a população não deveria ficar aterrada, pois a Providência já tinha mostrado o remédio eficaz para combater a doença, classificada de forma pejorativa como "judeu errante"2, a saber: o "venturoso sumo do limão". $\mathrm{O}$ medicamento teria produzido bons efeitos no Pará em 1855. Destarte, argumenta o texto, também obraria milagrosamente se estourasse no Cariri. Utilizando o discurso religioso, afirmava a proteção de Deus sobre os crédulos de "Sua infinita misericórdia". O ato misericordioso de Deus e o uso do limão permitiriam "encarar com o sangue frio essa epedemia e della zombarmos". A referência ao manejo do "milagroso" do limão no Pará é revelador vestígio de como a medicina do oitocentos assimilou remédios advindos dos saberes populares para tratar pessoas acometidas pelo cólera. Jane Beltrão argumenta que as ações políticas referentes aos socorros públicos durante a passagem do cólera no Pará "eram, embora a contragosto das autoridades sanitárias, sistematicamente alteradas pela ação dos envolvidos no flagelo" (2000, p. 847).Tendo em vista as adversidades daquela quadra, a pressão social exercida sobre as autoridades sanitárias pelas pessoas ameaçadas pelo cólera, fez artes de curandeiros, raizeiros e outros terapeutas populares no Pará serem abonadas por alguns médicos da província. Ao assimilar tais práticas, os acadêmicos "escudavam-se em procedimentos considerados científicos para evitar maiores alterações nas posições já conquistadas" pela medicina oficial, que buscava centralizar em suas mãos as artes de curar (Idem, p. 852).

Entre os "doutores" a enveredar por este caminho, a autora destaca Francisco da Silva Castro, presidente da Comissão de Higiene Pública do Pará, promotor de experimentos com limão, após saber que grupo de indígenas obtivera sucesso no combate ao cólera por meio do uso do 
cítrico. Tais experiências foram veiculadas pelo $O$ Araripe. Nele, lê-se cópia de relatório de autoria do médico, originalmente enviada pelo governo do Pará à presidência do Ceará. Esta remeteu o documento aos membros das comissões sanitárias instituídas no interior da província. Ao receber o relato, o presidente da comissão sanitária do Crato, Domingos José Nogueira Jaguaribe, pediu a reprodução à redação do semanário $O$ Araripe, "para que no caso de ser esta comarca acomettida da epidemia, seos habitantes estejam prevenidos".

Assim, O Araripe publicou na íntegra o experimento do Dr. Castro, incluindo listagem nominal de trinta pessoas tratadas, das quais apenas uma teria falecido, avalizando a suposta eficiência do antídoto. O relato ressalta a "extensa profusão de medicamentos que tem lançado mão os homens da sciencia desde remotos tempos por diversas partes do orbe para combater a medonha moléstia" do cólera e para a "fallibilidade de cada um delles". Para o facultativo, não estava longe o tempo da ciência "rasgar o véu" dessa moléstia, superando, assim, a falibilidade aludida. Inclusive, novo "facho de luz" era lançado sobre tal questão, o qual poderia "guiar a medicina para esses descobrimentos", pois o limão vinha se mostrando eficaz no tratamento do cólera. Conta a fonte que os testes com o limão começaram após audiência do Dr. Castro com o Bispo do Pará. D. José Afonso Torres retornava de viagem pastoral à Província do Amazonas, na qual ouviu relato sobre como "índios pescadores" utilizavam o sumo de limão na terapêutica dos coléricos. Os "pobres índios", diz o relatório, dirigiam-se numa canoa ao local da pescaria quando um deles caiu na água, "atacado fulminantemente" pelo cólera. Em lugar inóspito, os indígenas procuraram socorrer o doente com o que estava à volta. Um deles se lembrou de buscar limões presentes na canoa. As frutas foram espremidas e o sumo foi ingerido pelo colérico ao longo do dia. A medida teria implicado na célere reanimação do doente, logo tido como sarado.

A descoberta - conta Castro e Silva das propriedades clínicas do limão deu-se pela "graça celeste" inspirando os índios - classificados como "semisselvagens" - a usarem a fruta: "Oh! Providencia Divina, quanto sois Misericordiosa!
Como velaes pela sorte das vossas fracas creaturas!". As benesses da medicação foram se espalhando na medida em que outros doentes ficavam sãos: "Espalhou-se a nova da preciosa descoberta, correo de bocca em bocca a noticia; e todos quantos adoecerão por aquellas bandas usarão do mesmo remedio e todos sararão!!” (O ARARIPE,1856b, p. 3). Em consequência desta história, o clínico começou a usar limão no tratamento de pacientes, obtendo resultados positivos. Nas suas palavras, a "Providência" havia mostrado o remédio e o "cadinho da observação [científica] folgava em reconhecer [o limão] como favorável a mísera humanidade". Desta forma, a ciência legitimava os relatos chegados aos ouvidos de Castro e Silva pela boca de um "ungido do Senhor" - em referência ao bispo do Pará -, conforme o relatório, "escolhido" por Deus "para ensinar as suas ovelhas o remédio mais capaz de exterminar o mal, que as tem devorado, e que muito poderá ainda continuar a affligir e devastar o resto do nascente Império de S[anta]. Cruz".

Por outro lado, o relatório frisava: o uso da fruta como remédio não era novidade. Citava, inclusive, estudos parisienses do químico chamado Cavaillon, datados de 1832, ano do cólera na França, nos quais o limão foi apontado como medicamento capaz de debelar os vômitos dos coléricos. $\mathrm{O}$ autor afiançava não saber explicar a razão dos colegas haverem estancado as prescrições do suco cítrico contra o cólera, chegando mesmo a cair no "esquecimento". No entanto, era preciso dar sequência às investigações, pois o médico tinha fidúcia: a fruta era "terapêutico valioso" no combate ao cólera. É apropriado perceber como a suposta descoberta dos indígenas de Vila Franca a propósito da ação medicinal do fruto contra tal moléstia foi representada pelo Dr. Castro e Silva. O emprego do limão por tais indivíduos foi interpretado pelo médico como obra da Providência Divina. Dessa forma, os pescadores que teriam usado inicialmente o medicamento, passam de atores principais para meros coadjuvantes, pois a inspiração não advinha originalmente deles, mas sim da "graça celeste". Por outro lado, ao invocar as experiências científicas exercidas decênios antes na França, bem como as realizadas em sua clínica particular, 
o médico paraense também retirava o brilho da obra daqueles "semisselvagens", como os adjetivou pejorativamente. Todavia, malgrado negados pela força da providência divina e da ciência, é significante apreender o modo pelo qual as práticas daqueles indígenas permaneceram sendo utilizadas pelos facultativos no combate àquela epidemia, sendo, ainda, propaladas pela imprensa do momento.

A narrativa a respeito do limão inspirou interessante escrito com censuras contundentes à medicina. $\mathrm{O}$ artigo, sem assinatura de autor, saiu na seção "Comunicados". Segundo o texto, Deus teria dois fins quando resolveu mandar o cólera:

Parece que quando Deos mandou a epidemia actualmente, foi para dois fins: um para castigar ao seo povo contra os dilictos commetidos contra sua divina lei; e o outro para um total desengano do que é a rançosa Magica, que a muitos annos apareceo sobre a face da terra com o titulo de - Medicina -, que toda composta de sofismas, dispoem da especie humana, como bem lhe parece, sem attender, que a custa do suor desta miserável especie tem della adquerido tanta fama; e para tanto tem chegado sua boa fé, e credulidade! (O ARARIPE, 1856c, p. 3).

Apreende-se na citação forma nada amistosa de se aludir à medicina, exposta como "rançosa mágica", tomada de enganos e exploradora da boafé da humanidade. A ideia de Deus usando o cólera para desenganar a ciência médica, possivelmente, estava vinculada a percepção social de que os doutores não ofereciam até então, meios efetivos de estancar os surtos da doença pelo mundo e, notadamente, no Brasil, sempre deixando cifras mortuárias altas por onde zanzava ${ }^{3}$. Nesta acepção, o apontamento de pessoas tidas como "rústicas", sem títulos acadêmicos e avessas à ciência clínica, a encontrar antídotos simples com efeitos práticos na terapêutica da moléstia era algo assombroso:

É coisa espantosa ver-se, que, alli uns rusticos, e simples pastores de gados por meios de suas observações chegasse a descubrir a vertude da erva Menthrasto; acolá um pobre balseiro a do summo do limão, como antídotos contra a epidemia que tantas victimas tem feito; [...] Não menos (é presumivel) terão feito os indiginas das Tribus selvagens com outras ervas silvestres! Estes virtuosos cidadãos, dotados de almas generosas, e de corações mais philantropicos ensinarão ou annunciarão ao mundo (gratuitamente) os trabalhos de suas observações; e sem esperança de recompença alguma. É até aonde se pode diser: almas cândidas: corações generosos; cidadãos prestantes; e verdadeiros amigos do seo proximo. Outro tanto se poderá diser de nossos médicos? Risum... (O ARARIPE,1856c, p. 3).

A fonte faz menção de louvor ao uso do sumo do limão pelos silvícolas pescadores do Pará, contada há pouco. Há, igualmente, referência a pastores que teriam descoberto as virtudes do mentrasto, também conhecido pelas denominações hortelã-do-mato e hortelã-silvestre. O hipotético descobrimento por pastores espanhóis do emprego da erva nos cuidados dos coléricos tinha sido divulgado na edição anterior (O ARARIPE, 1856d, p. 4). Portanto, "rústicos" e "simples" pastores e índios - apontados como autores da descoberta das propriedades salutares do limão e da hortelã tinham se comportado de forma mais "filantrópica" que os discípulos de Hipócrates. Por isso, foram adjetivados: "virtuosos cidadãos", "almas generosas" e "verdadeiros amigos".

Em país escravocrata e de disparidades sociais gritantes como o Brasil do século XIX, no qual a cidadania era benefício de poucos, nomear indígenas, marginalizados até hoje, como cidadãos era apenas exercício retórico. Mas, não deixa de atrair atenção o fato de se enaltecer tais personagens em detrimento dos médicos. Estes, expressa o jornal, não exibiriam a mesma abnegação e "corações generosos" daqueles. Para corroborar a asseveração, $O$ Araripe exibiu as supostas reações de certos doutores do Ceará, quando convidados para oficiarem nas comissões sanitárias nomeadas em 1856:

Alli hum [médico] por ir faser uma ligeira visita aos acommetidos da epidemia fora da capital exigio do 
governo a bagatela de 400 garrafas de vinho do Porto: 10 vitelas 50 carneiros; e 500 galinhas. Não sei como não pedio um galo! acolá, outros se negão a se encarregar do curativo do misero povo; mais para alli um não quer contractar [...] Triste é por certo a condição da infelis humanidade, quando em suas mais aflictas agonias é despresada por seos proprios similhantes! (O ARARIPE, 1856c, p. 3).

Os facultativos cearenses aludidos no impresso eram representados como interesseiros, exigindo fortunas para socorrer moradores das localidades interioranas, temerosas com a probabilidade do advento do cólera. Em ocasião de aflição e agonia, os médicos eram acusados de colocar interesses particulares acima do bem da "infeliz humanidade". Tendo em conta o teor das denúncias expostas na citação, os leitores do jornal devem ter abarcado em que se baseavam os louvores feitos à "filantropia" dos silvícolas paraenses. Nessas condições, com a manifesta recusa de determinados doutores em oficiar no interior da província, o artigo indagava: de que valeria as diligências do governo - visíveis na instituição de comissões sanitárias e no envio de medicamentos - se não haveria médicos para cuidar dos doentes? Ficaria na mão de quem a aplicação dos remédios? Com os "bacharéis e padres" de Crato? Portanto, finalizava a fonte, a solução era esperar a ajuda do Céu: "O povo desta cidade que ponha os olhos em Deos, e rogue a sua Padroeira que não permita sejamos atacados da epidemia, que morreremos a mingoa" (O ARARIPE, 1856c, p. 3).

Se $O$ Araripe, ao longo das laudas consagradas ao cólera, deu azo para que médicos divulgassem orientações no trato dos adoentados, os trechos citados nos últimos parágrafos evidenciam como o periódico não deixou de tecer admoestações mordazes à real eficácia dos acadêmicos em medicina no auxílio aos pacientes, repreendendo aqueles, inclusive, moralmente, ao aludir a ambição por salários altos, impelindo ao não socorro das localidades sertanejas. Por outro lado, o conjunto de textos apregoados n'O Araripe assinala também as multifacetadas teorias médicas da quadra em tela - que se altercavam no fito de conquistar a aceitação pública, enquanto milhares de pessoas eram fustigadas pelo cólera -, bem como para uma circularidade de saberes, fazendo medicamentos tradicionais (ervas, aguardente, frutas etc.) entre a população mesclarem-se com produtos químicos e práticas terapêuticas oficiais.

\section{Entre clisteres e chás de folha de laranjeira}

Em meados do século XIX, as medidas sanitárias seguidas no trato do cólera, ordinariamente, se relacionavam com duas teorias seculares que procuravam explicar a propagação das doenças: o infeccionismo e contagianismo. Para melhor juízo delas naquele contexto, é interessante recorrer ao "Dicionário de medicina popular", de autoria do médico polonês, Pedro Luiz Napoleão Chernoviz. Para o dicionarista, a infecção seria "exercida na economia [do organismo] por miasmas morbificos", devido à ação que "substancias animaes e vegetaes em putrefação exercem no ar ambiente". Já o contágio era entendido como "a propriedade que tem certas molestias de se communicar de um a outro individuo pelo contacto, ou por intermédio do ar" (1890, p. 676).

Para Dina Czeresnia, até o século XVI, não havia conflito entre as noções de contágio e miasma. Pelo contrário, ambas estavam embasadas na longa tradição hipocrática dos humores, no entendimento das enfermidades como decorrência de possessões e magias, bem como de fenômenos astrológicos e divinos. Maior controvérsia entre as duas explicações só teria emergido entre os séculos XVII e XIX, com o aumento da urbanização europeia, sendo causada por divergências a respeito das medidas sanitárias e profiláticas no trato das epidemias. Nesse sentindo, via de regra, os contagionistas se posicionavam em prol das quarentenas, significando um severo cerceamento e vigilância sobre os doentes. Já os adeptos da teoria dos miasmas, ao relacionarem a origem das epidemias à constituição atmosférica, acentuavam ações direcionadas ao controle e limpeza ambiental (CZERESNIA, 1997, p. 84). 
Debate profícuo na historiografia sobre tais paradigmas levanta hipóteses interessantes a respeito dos sentidos políticos adquiridos no século XIX: a teoria do contágio estaria mais próxima ao padrão absolutista, senhorial ou patriarcal, daí o porquê das autoritárias medidas de sequestro e quarentena defendidas pelos adeptos da mesma. Por outro lado, os infeccionistas, tenderiam para o modelo liberal, combatendo qualquer medida limitadora da circulação de pessoas e mercadorias. Para este grupo, era imprescindível higienizar o ambiente, em vez de instituir quarentenas. Deste modo, as teses infeccionistas convinham "às nações e comunidades comerciais, para as quais qualquer atraso no livre trânsito de mercadorias causava muitos prejuízos" (ROSEN, George, 1994, p. 205). Entretanto, Sidney Chalhoub expõe como o paradigma da infecção, ao colocar os miasmas em primeiro plano, abonava maior combate às práticas populares, mediante o discurso higienista. $\mathrm{Ou}$ seja, os infeccionistas também obravam de forma autoritária na execução de projetos sanitários. Malgrado a contenda sobre os sentidos políticos da infecção e contágio, Chalhoub mostra as duas teorias se combinando com frequência, de formas imprevista e original (1996, p. 169).

N'O Araripe é perceptível a presença de orientações infeccionistas e contagionistas, com preponderância das primeiras sobre as segundas. Em 1856, quando localidades pernambucanas próximas ao Crato foram acometidas pela epidemia, escrito de capa foi veiculado, requerendo das autoridades policiais a disposição de "cordões sanitários" nas fronteiras, típico artifício profilático de inspiração contagionista. Todavia, o mesmo texto apresenta o "clima do Cariri" como o mecanismo de defesa final. O risco da transmissão via "atmosfera" partia da crença nas exalações infecciosas:

Ei-lo pois que se aproxima [o cólera], malogradas nossas bellas esperanças. Enquanto nos restão alguns dias, aproveite a policia em conjurar o mal com os recursos a sua desposição. Bom será empregar já toda a força dos dous destacamentos da comarca em um cordão sanitario, que com toda a severidade prive as relações entre os dous pontos, medida muitas veses empregada na Europa com felis sucesso, e unica que nos pode presevar da invasão [...]. Algumas pessoas que se tiverem inoculados do mal não transporão a linha, e nosso único perigo ficará na athmosphera, o que, graças a diversidade do clima, não é muito para assustar (O ARARIPE, 1856e, p. 1).

Tendo em vista a inquietação com a pureza do ar, em abril de 1856, O Araripe recomendava método preventivo fundamentalmente embasado na teoria da infecção pelos miasmas, propondo fumigação de enxofre nas residências:

Um engenheiro de minas na Europa escreveu a um seu amigo dizendo lhe que para escapar do cholera queimasse de quando em quando pequenas porções de flor de enxofre e de modo que o cheiro desta fomigação se conservasse durante o dia em casa. Segundo diz o mesmo engenheiro foi deste modo que se evitou o desenvolvimento da epidemia na povoação em que elle se achava. Por ultimo affiança que o cheiro do enxofre em combustão, posto que pareça, não é prejudicial, e accrescenta que em nenhuma fabrica, onde se faça uso do enxofre tem apparecido casos do cholera (O ARARIPE, 1856f, p. 3).

A reivindicação de aperfeiçoamentos higienizadores na urbe, representados pelos profissionais liberais, comerciantes e fazendeiros financiadores d'O Araripe como símbolos de civilidade, indicia a força da crença do caráter maléfico das exalações mal cheirosas. Na conjuntura de aproximação do cólera em relação ao Cariri, da cadeia pública à matriz de Nossa Senhora da Penha pareciam emanar os miasmas ameaçadores. Em novembro de 1855 , em escrito de capa, $O$ Araripe defendeu ser menos respeitável criar cordões de isolamento - vedando a circulação de pessoas e produtos - do que as autoridades públicas agirem sobre locais considerados de infecção:

As medidas sanitarias, que na quadra actual mais precisamos, é sem duvida que os funcionarios publicos lancem suas vistas sobre a cadeia publica, esse foco pestifero, que tem comsumido as vidas de muitos infelises, e causa 
primaria de algumas molestias aparecidas nesta cidade; as sepulturas de nossa Matris que se tornão insupportaveis, quando se abrem para os enterramentos no ceio das ruas; becos, quintaes, que ainda existem com pudridões; as poças e enxurradas de aguas, de que fasemos uso nos misteres da vida (O ARARIPE, 1855b, p. 1).

Se a teoria infeccionista preponderou sobre a contagionista n'O Araripe, a contenda entre alopatia e homeopatia, marca dos debates médicos de meados do oitocentos, foi também perceptível. $\mathrm{O}$ semanário promulgou terapêuticas embasadas nos dois sistemas. Também achincalhou a disputa entre os mesmos, assinalando a ineficiência de ambos, sem tecer distinção valorativa muito clara, malgrado as fortes diferenças que caracterizavam as práticas e receitas delas advindas. Os alopatas preferiam o uso de drogas, cáusticos, sangrias, eméticos, vesicatórios, purgantes e clisteres - injeções no reto que aspiravam combater desarranjos intestinais - no tratamento das moléstias. Já os homeopatas empregavam recursos menos drásticos, sendo partidários do princípio dos “infinitesimais”, para qual quanto menor fosse a dose do medicamento, geralmente na forma de glóbulos levemente adocicados e dissolvidos em água, maior seria a eficácia (PORTER, 2004). Ao versar a respeito da querela entre os dois sistemas, $O$ Araripe zombava da ineficiência de ambos, pois as "drogas" e "glóbulos", em vez de curar, chacinavam na mesma proporção, como explana curto e sarcástico texto impresso em 1856, intitulado "Conto popular":

Tom.....tom tom.....

Quem bate ahi?

Sou eu.

Ah! é o sr. Cholera? como está o sr. Cholera? donde vem o sr. Cholera? para onde vae o sr. Cholera?

Vou até alli assim ao A.....

Quantas pessoas pretende lá matar?

Somente tresentas.

Passão se alguns dias, e de novo ouve o pobre homem bater-se-lhe à porta.

Quem bate ahi?....

Criado do sr. Braz....

Ah! é o sr. Cholera!....... como passa o sr. Cholera? quantas pessoas matou o sr. Cholera?
Matei as mesmas 300, mas as drogas e globos matarão outras 300, e o medo matou ainda mais (O ARARIPE, 1856g, p. 2).

Irônica, a pequena história é reveladora. A eleição do título "Conto popular", de partida, já tinha objetivo claro: passar a ideia de anedota admitida por todos, alvo do deboche público. No texto, o cólera surge personificado em alguém inesperadamente batendo à porta. Outro incógnito personagem, Sr. Braz... (referência ao nome do país, Brasil?) atende o visitante, passando a lhe fazer indagações. O cólera informa ir a um lugar de nome iniciado pela letra $A$ (talvez ao Araripe, entendido como a região onde se encontra a chapada de mesmo nome, ou seja, ao Cariri) onde trucidaria trezentas pessoas. Depois de visitar a localidade em questão, a doença retorna à mesma porta do senhor Braz. Quando inquirido sobre os mortos, afirma ter matado os três centos prometidos. Contudo, outros tantos faleceram pela ação de drogas e dos globos e mais trezentas pessoas finaram de medo 4 . Destarte, das novecentas pessoas mortas durante a inspeção do cólera, tão somente um terço seria decorrência direta da moléstia.

Não obstante, interessa aqui destacar: ao se referir a drogas e glóbulos, o texto satirizava alopatas e homeopatas. Ao tratar da querela entre os dois sistemas, ironizava a ineficiência de ambos, pois em vez de curar, assassinaram em igual proporção. Por conseguinte, a pequena história do cólera batendo à porta e as outras admoestações à medicina, acabam revelando questões e dúvidas inerentes àquele contexto, no qual não se conheciam mecanismos totalmente apropriados para debelar a manifestação da doença a se avizinhar. Logo, $O$ Araripe não deixou de refletir as celeumas médicas subjacentes àquela conjuntura, bem como as limitações no trato aos coléricos.

Mesmo não isentando a medicina de censuras, $O$ Araripe esteve bastante atento às recomendações advindas dos facultativos. As ideias higienistas, defendidas pela "medicina social" (REIS, 1991), foram apropriadas pelas elites locais no escopo de legitimar as reformas urbanas tidas como condizentes a urbes ditas civilizadas, as 
quais pretendiam se identificar, na busca de maior legitimidade social. Por outro lado, na quadra assinalada pela aproximação e pela manifestação do cólera no Cariri, o periódico procurou imprimir sistematicamente os conselhos médicos que lhe chegavam às mãos, seja por meio do contato direto estabelecido entre a redação e alguns doutores ou da reprodução de textos impressos originalmente em outros órgãos de imprensa. Neste sentido, tanto princípios homeopáticos como alopáticos ocuparam espaços no semanário ${ }^{5}$. Na conjuntura tensa - ante as notícias a respeito dos milhares de brasileiros fulminados pelo cólera e a falta de médicos residindo no Cariri -, os textos transcritos e publicizados pelo $O$ Araripe buscavam: sintetizar como o fenômeno epidêmico estava sendo ventilado pela ciência do período, para os caririenses, por si só, pudessem "curá-la, quando se desenvolver o mal entre nós" (O ARARIPE, 1855a, p. 2.). Pretendiam assim, captar e divulgar orientações práticas de como proceder no caso do aparecimento da epidemia no Ceará, daí, pois, as razões dos longos artigos publicados com múltiplas orientações profiláticas. No geral, tais artigos eram assinados por médicos, brasileiros ou estrangeiros, e tinham sido publicados originalmente em outros periódicos. Ao reproduzi-los, O Araripe nem sempre anunciou o nome dos autores. As orientações contidas nos textos iam da simples indicação de remédios até sugestões aos senhores de escravos, no intuito de evitar a contaminação dos cativos pela epidemia, como no artigo firmado por Dr. Joaquim d'Aquino Fonseca, médico pernambucano. Para ele, o "trabalho excessivo", quer "intelectual" ou "corpóreo", concorria para o desenvolvimento do cólera. Por isso, era forçoso evitar a labuta em horas de muito calor ou umidade. Por isso, os proprietários de engenhos e estabelecimentos rurais deviam impedir a escravaria de labutar pela madrugada ou noite, quando a umidade favorecia o resfriamento dos corpos. Durante o dia, era recomendável evitar que os cativos ficassem expostos ao sol nas horas de maior calor, dando, ainda, aos mesmos uma hora de descanso após cada refeição. Pela manhã, não era conveniente deixar os escravos irem para o trabalho em jejum. Seus donos deveriam oferecer xícaras de café puro ou pequenos cálices de genebra ou aguardente de cana ao alvorecer (O ARARIPE, 1856h, p. 3). A higiene corporal preocupava o Dr. Fonseca: os senhores deviam "obrigar seus escravos a banharem se uma vez por dia, fazendo-o de modo que não haja supressão da transpiração ou resfriamento". Como a aglomeração dos cativos favorecia a disseminação do cólera, o médico alvitrava uma subdivisão, pois não era bom muitos sujeitos dormindo em "lugares acanhados", como em certas senzalas. De preferência, deviam ser alocados em casas situadas em pontos altos e arejados, onde pequenas fogueiras podiam ser acesas à noite, para combater os miasmas.

A inquietação do artigo em guiar os senhores sobre os procedimentos com a escravaria não repousava nos princípios humanitários. A própria orientação sobre coisas aparentemente básicas - oferta de refeições diárias, regras de higiene corporal, entre outras recomendações elencadas -, assinala a precariedade das condições de vida a que os cativos estavam subordinados. Contudo, o cólera representava prenúncio grave aos interesses dos senhores, pois muitos escravizados feneceram nos surtos do oitocentos. Pelo visto, $O$ Araripe, ao apregoar as considerações do Dr. Aquino ambicionou acordar as elites locais para os riscos do cólera, afinal escravos eram mercadorias caras e raras no Cariri, daí a preocupação em conservá-las vivas para melhor explorá-las.

De modo geral, os artigos médicos procuravam orientar, passo a passo, ao público leitor como proceder por ocasião da chegada da peste. Alguns deles eram ricos em minúcias, trazendo conselhos para diferentes fases da doença. Consequentemente, os leitores eram instados a adotar postura de observação sistemática de toda anamnese do cólera. Diante de enfermidade cujo presságio basilar era a diarreia, aconselhava-se contar o número de evacuações diárias e verificar se havia alteração na consistência das fezes ao longo do tempo. Para cada sintoma ou estágio, havia remédios ou técnicas específicas: o esfriamento do corpo era combatido com fricções de álcool, pimenta etc.; para a ânsia de vômitos, a sugestão era a ipecacuanha ou o azeite morno com uma "rama 
de pena”; chá de hortelã com láudano combatia a diarreia, apesar de, a partir de determinado estágio, a última substância passar a ser considerada veneno; e assim deveriam seguir os procedimentos, até convalescença ou morte da pessoa acometida.

No grosso dos textos escritos por facultativos, deparei-me com a indicação de substâncias químicas em voga na medicina da época, comercializadas nas boticas, sobressaindose: enxofre, amoníaco, clorofórmio, ópio, éter, láudano, óleo de rícino etc. Pari passu houve a enumeração de ervas e outros produtos comuns nas residências e quintais das pessoas: alho, pimenta, hortelã, limão, folhas de laranjeira, macela, entre outros. Diante da crença no caráter revigorante do álcool, o vinho e a cachaça - esta última, bebida das mais populares do Brasil desde os tempos coloniais, e produzida em abundância nos engenhos de cana ao sopé da chapada do Araripe - também receberam menções constantes nos artigos. A junção de produtos populares e fármacos comercializados nas boticas corrobora as considerações de Beltrão sobre como a medicina da época, apesar do processo de institucionalização, não deixou de fazer concessões às artes de curar e saberes populares no tempo do cólera (BELTRÃO, 2000). O estouro da epidemia acabou expondo as debilidades da medicina e a incapacidade de inibir o cólera efetivamente. Neste sentido, na busca por remédios capazes de oferecer alguma resistência ao mal, os facultativos fizeram experiências que acabaram abonando práticas consagradas pelos saberes populares, algumas herdadas do passado colonial. O uso de chás, frutas, temperos e de outros produtos cotidianamente utilizados pela população na lida dos achaques e na confecção de medicamentos que buscavam minorar os efeitos do cólera, apontam para uma circularidade de saberes publicizada no jornal.

A ideia de "circularidade cultural" ganhou proeminência entre os historiadores por superar a tese da existência de suposta dicotomia entre diferentes níveis de cultura (cultura letrada $\mathrm{x}$ cultura popular). Em vez de enxergar a produção cultural dividida em polos estanques, o conceito propõe um olhar que valoriza o caráter dinâmico e dialógico da mesma: as trocas de mão dupla ${ }^{6}$
Aplicado ao objeto de estudo deste artigo, o uso do conceito de circularidade cultural permite maior compreensão de como as orientações científicas se mesclaram com os conhecimentos populares no trato do cólera, vistas por meio das matérias publicadas n'O Araripe. Exemplo disto pode ser visualizado no artigo do Dr. Antonio Manoel de Medeiros, médico comissionado pelo governo do Ceará para socorro dos cratenses nas epidemias de 1862 e 1864. O texto mistura fármacos de botica com ervas e temperos presentes nos quintais, bem como outros produtos disponíveis nas cozinhas da maioria das pessoas. Nele, há a preocupação em descrever a evolução da doença passo a passo: nos primeiros sinais do cólera, o doente devia abster-se de comer, agasalhar-se bem, fazer escalda-pés com sal ou mostarda, aplicar sinapismos, beber, de hora em hora, uma infusão de macela, hortelã pimenta e folhas de laranjeira, com algumas gotas do elixir "paregórico americano". Se o doente estivesse a lançar tudo o que bebesse, recomendava-se a aplicação de clisteres a base de láudano e o uso de sudoríferos. Caso não houvesse melhora no quadro, Dr. Medeiro receitava a ingestão de pílulas compostas de "extrato gomoso de ópio", "pós de dower" e "goma arábica". Tais pílulas deviam ser tomadas de "meia em meia hora, de hora em hora, ou de duas em duas horas, conforme a intensidade na resistência do mal". O médico afiançava que a diarreia e os vômitos desapareceriam com o uso correto das pílulas. Não obstante, se em vez de aliviar tais sintomas, o doente mostrasse sinais do "cólera álgido" [resfriamento do corpo], era necessário garantir a retomada imediata do calor corporal. A ação em prol da elevação da temperatura se daria em duas frentes: internamente, por meio da ingestão de uma infusão à base de "café preto bem forte, do vinho do Porto ou de Madeira, aguardente ou álcool, ajuntando-se lhe de 8 a 20 pingos do licor stragnoff"; e externamente, pela fricção de uma baeta, flanela ou escova, embebida em pimenta malagueta, mostarda ou cantárida. Complementando tal tratamento, "o sumo do limão em doses pequenas repetidas e progressivamente maiores, começando por uma colhersinha", seria apropriado para o doente que não estivesse totalmente álgido e demonstrasse muita sede $(\mathrm{O}$ ARARIPE, 1864, p. 3). 


\section{Considerações finais}

Ao longo do artigo, busquei mostrar as orientações e receitas que $O$ Araripe publicou sobre o cólera em meados do oitocentos. Tendo em vista que praticamente inexistiam médicos no Cariri cearense do período, o semanário cratense tomou para si o papel de informar a população a respeito das discussões clínicas sobre a doença, no intuito de prepará-la para agir quando da manifestação epidêmica.

Tais considerações realçam a tese basilar da historiografia das doenças, para qual o fenômeno do adoecer não deve ser visto apenas como algo natural, desprovido de outros significados além do biológico. $\mathrm{O}$ que os historiadores dedicados ao assunto propõem é o olhar problematizado sobre as representações socioculturais que cercam as enfermidades: a dimensão biológica delas não deixa de ser cercada por questões sociais, culturais, econômicas, políticas, procurando dar significados e respostas a elas.

O caso do cólera n'O Araripe é exemplo da historicidade da doença. Em época marcada pelo medo em torno da moléstia, umas das mais letais do século XIX, as representações impressas no periódico foram de diversidade espantosa. Como a medicina-científica estava enredada em disputas internas e não oferecia respostas conclusivas sobre a doença, a abundância de artigos do jornal aponta para a circularidade de saberes e representações múltiplas, que embaralhavam de forma criativa orientações miasmáticas e contagionistas, tratamentos alopatas com homeopatas, fármacos químicos com remédios feitos a base de ervas, frutas e outros produtos populares.

\section{Notas}

$1 \mathrm{O}$ jornal em questão se encontra na Hemeroteca Digital da Biblioteca Nacional. Disponível em: $<$ http://bndigital. bn.gov.br/hemeroteca-digital/>. Optei, neste artigo, por manter a transcrição da grafia original das fontes.

2 Peter Burke, tratando da cultura popular da Europa da Idade Moderna, conta uma velha história que ajuda a melhor compreender a metáfora do "judeu errante". Durante a via-crúcis, quando Jesus levava nos ombros a cruz, um sapateiro judeu teria o impedido de descansar. Devido a essa atitude, tal sapateiro foi condenado por Deus a vaguear pelo mundo desde então (BURKE, 1989, p. 191-192). Versões desta história foram sendo recontadas em vários contextos. Não por acaso, quando dos surtos de peste no medievo, houve perseguição generalizada a judeus e viajantes, acusados de envenenar fontes e espalhar a doença em vilas e cidades por onde passavam (DELUMEAU, 1989).

3 Doença infectocontagiosa, o cólera é causado pela ingestão de água ou alimentos contaminados pela bactéria Vibrio cholerae - descoberta em 1883, pelo médico alemão Robert Koch (1843-1910). Nos casos mais graves, ao se instalar no intestino humano, o vibrião causa, após um período de incubação de um a quatro dias, uma profusa diarreia aquosa e vômitos, com considerável perda de sais minerais e água, que pode chegar a uma média de 1,5 litros por hora. A reposição imediata dos sais e líquidos perdidos pela diarreia é a forma mais eficiente de tratamento dos doentes, e, quando bem administrada, pode reduzir a letalidade para menos de $1 \%$. Contudo, em meados do século XIX, período pesquisado neste artigo, apenas se especulava as formas de contágio e tratamento adequado para combater sua manifestação, a despeito da terrível marcha que fazia pelo mundo, percorrendo o Oriente e o Ocidente, sendo "responsável por trinta ou quarenta milhões de mortes durante o século XIX, em todas as latitudes" (SOURNIA, RUFFIE, 1986, p. 124).

4 A declaração de que três centenas de pessoas expiraram por medo diz respeito à antiga crença na qual o abatimento moral e o temor em época de epidemia predispõem os indivíduos a auferir o contágio (DELUMEAU, 1989, p. 125), opinião validada pelos discursos de médicos brasileiros do século XIX, que, entre outras coisas, queriam disciplinar o dobre de sinos das igrejas pelos finados, tendo em vista a percepção de tais sons como responsáveis por atingir os nervos da população, debilitando-a ao ponto de favorecer o adoecimento (REIS, 1991, p. 264-265).

5 Em 1856, O Araripe reproduziu texto assinado por Ignácio Manoel de Lemos, morador da Cidade da Paraíba, louvando o uso homeopático da "tintura sulfúrica" e do "espírito de cânfora". O autor citava os resultados maravilhosos obtidos por essas substâncias no trato do cólera em Madri e Porto. O uso fora tão satisfatório, que os médicos alopatas da última cidade teriam se rendido às mesmas, deixando de lado rivalidades ao carregar em suas "algibeiras os vidrinhos deste dous medicamentos, e em qualquer parte levantavam-se bons os fulminados de cholera". Ao exaltar a atitude destes últimos, o texto de Ignácio Manoel de Lemos terminava provocando os alopatas pernambucanos, indagando se estes repetiriam a ação daqueles "amigos da humanidade" (O ARARIPE, 1856i, p. 3-4).

6 A historiografia deve o desenvolvimento da concepção de circularidade cultural aos estudos produzidos por 
Mikhail Bakhtin e Carlo Ginzburg. Ao tratar da cultura popular da Idade Média e do Renascimento, especialmente no que diz respeito à historicidade do riso e das festas populares, Bakhtin se voltou para a obra de Rabelais, proeminente literato da Europa medieval. Nessa fonte de pesquisa, enxergou a possibilidade de "iluminar a cultura cômica popular de vários milênios", já que percebia o letrado Rabelais como eminente porta voz desta cultura na literatura. A produção erudita rabelaisiana estaria mergulhada no linguajar, imagens e bufonices populares, característicos do recorte historiográfico analisado por Bakhtin: “[...] É na obra de Rabelais que o riso da Idade Média encontrou sua expressão suprema” (1993, p. 84). Inspirado na linha traçada por Bakhtin, Ginzburg forjou a terminologia circularidade cultural, ao tratar do moleiro Menocchio, morto pela inquisição no século XVI, por suas ideias sobre a criação do mundo e sociedade de sua época, incluído aí crítica feroz aos dogmas, sacramentos e atitudes da Igreja Católica. Advindo do meio popular - sendo herdeiro da tradição oral camponesa de difícil datação -, Menocchio sabia ler e escrever, fato raro para os moleiros do período. Contudo, na incursão pelo mundo da cultura letrada e elaboração de sua cosmogonia, o moleiro não reproduzia simplesmente as tese dos autores que lera: produziu reelaboração original das leituras feitas, na qual a cultura oral funcionava como um filtro: "Menocchio triturava e reelaborava suas leituras, indo muito além de qualquer modelo preestabelecido [...]. Não o livro em si, mas o encontro da página escrita com a cultural oral é que formava, na cabeça de Menocchio, uma mistura explosiva” (1987, p. 103).

\section{Referências}

BAKHTIN, Mikhail. A cultura popular na Idade Média e no Renascimento: o contexto de François Rabelais. São Paulo: Hucitec; Brasília: Editora da UnB, 1993.

BELTRAO, Jane Felipe. A arte de curar dos profissionais de saúde popular em tempo de cólera: Grão-Pará do século XIX. História, Ciências, Saúde - Manguinhos, v. 6, supl., p. 833-866, 2000.

BURKE, Peter. Cultura popular na Idade Moderna. São Paulo: Companhia das Letras, 1989.

CHALHOUB, Sidney. Cidade febril. Companhia das Letras, 1996.

CHERNOVIZ, Pedro Luiz Napoleão. Diccionario de medicina popular e das sciencias accessorias para uso das famílias. 6. ed. Paris: A. Roger \& F. Chernoviz, 1890.
CZERESNIA, Dina. Do contágio à transmissão: uma mudança na estrutura perceptiva de apreensão da epidemia. História, Ciências, Saúde Manguinhos, v. 4, n. 1, p. 75-94, 1997.

DELUMEAU, Jean. História do medo no Ocidente. São Paulo: Cia. das Letras, 1989.

DINIZ, Ariosvaldo da Silva. Medicinas e curandeirismo no Brasil. João Pessoa-PB: Editora Universitária da UFPB, 2011.

GINZBURG, Carlo. O queijo e os vermes. São Paulo: Cia. das Letras, 1987.

HERZLICH, Claudine. A problemática da representação social e sua utilidade no campo da doença. Physis, v. 15, supl. 10, p. 57-70, 2005.

O ARARIPE, n. 10, p. 2, 8 set. 1855a. Coleção da Hemeroteca Digital da Biblioteca Nacional. Disponível em: <http://bndigital.bn.gov.br/ hemeroteca-digital/>. Acesso em: 6 de out. 2017.

n. 20, p. 1, 17 nov. 1855b. Coleção da Hemeroteca Digital da Biblioteca Nacional. Disponível em: <http://bndigital.bn.gov.br/ hemeroteca-digital/>. Acesso em: 6 de out. 2017.

n. 26, p. 3, $1^{\circ}$ jan. 1856b. Coleção da Hemeroteca Digital da Biblioteca Nacional. Disponível em: <http://bndigital.bn.gov.br/ hemeroteca-digital/>. Acesso em: 6 de out. 2017.

n. 27, p. 4, 5 jan. 1856a. Coleção da Hemeroteca Digital da Biblioteca Nacional. Disponível em: <http://bndigital.bn.gov.br/ hemeroteca-digital/>. Acesso em: 6 de out. 2017.

n. 33, p. 3, 16 fev. 1856h. Coleção da Hemeroteca Digital da Biblioteca Nacional. Disponível em: <http://bndigital.bn.gov.br/ hemeroteca-digital/>. Acesso em: 6 de out. 2017. , n. 36, p. 4, 8 mar. 1856d. Coleção da Hemeroteca Digital da Biblioteca Nacional. Disponível em: <http://bndigital.bn.gov.br/ hemeroteca-digital/>. Acesso em: 6 de out. 2017. 
, n. 37, p. 3, 15 mar. 1856c. Coleção da Hemeroteca Digital da Biblioteca Nacional. Disponível em: <http://bndigital.bn.gov.br/ hemeroteca-digital/>. Acesso em: 6 de out. 2017.

n. 41, p. 3, 19 abr. 1856f. Coleção da Hemeroteca Digital da Biblioteca Nacional. Disponível em: <http://bndigital.bn.gov.br/ hemeroteca-digital/>. Acesso em: 6 de out. 2017.

n. 42, p. 1, 26 abr. 1856e. Coleção da Hemeroteca Digital da Biblioteca Nacional. Disponível em: <http://bndigital.bn.gov.br/ hemeroteca-digital/>. Acesso em: 6 de out. 2017.

n. 43 , p. $3-4,3$ maio 1856i. Coleção da Hemeroteca Digital da Biblioteca Nacional. Disponível em: <http://bndigital.bn.gov.br/ hemeroteca-digital/>. Acesso em: 6 de out. 2017.

, n. 44, p. 2, 10 maio 1856g. Coleção da Hemeroteca Digital da Biblioteca Nacional.
Disponível em: <http://bndigital.bn.gov.br/ hemeroteca-digital/>. Acesso em: 6 de out. 2017. n. 307, p. 3, 13 maio 1864. Coleção da Hemeroteca Digital da Biblioteca Nacional. Disponível em: <http://bndigital.bn.gov.br/ hemeroteca-digital/>. Acesso em: 6 de out. 2017.

PORTER, Roy. Das tripas coração. São Paulo: Record, 2004.

REIS, João José. A morte é uma festa. São Paulo: Companhia das Letras, 1991.

ROSEN, George. Uma história da saúde pública. São Paulo: Hucitec,1994.

SOURNIA, Jean-Charles; RUFFIE, Jacques. As epidemias na história do homem. Lisboa: Edições 70, 1986. 